\title{
A comparative study of conventional and supercritical fluid extraction methods for the recovery of secondary metabolites from Syzygium campanulatum Korth ${ }^{\#}$
}

\author{
Abdul Hakeem MEMON ${ }^{1}$, Mohammad Shahrul Ridzuan HAMIL ${ }^{1}$, Madeeha LAGHARI ${ }^{1}$, Fahim RITHWAN ${ }^{2}$, \\ Salman ZHARI ${ }^{2}$, Mohammed Ali Ahmed SAEED ${ }^{1}$, Zhari ISMAIL ${ }^{\dagger 1}$, Amin Malik Shah Abdul MAJID ${ }^{3}$ \\ ( ${ }^{1}$ Department of Pharmaceutical Chemistry, School of Pharmaceutical Sciences, Universiti Sains Malaysia, 11800 Minden, Penang, Malaysia) \\ ( ${ }^{2}$ Center of Lipids Engineering and Applied Research (CLEAR), Ibnu Sina Institute for Scientific \& Industrial Research (Ibnu Sina ISIR), \\ Universiti Teknologi Malaysia, 81310 Johor Bahru, Johor, Malaysia) \\ ( ${ }^{3}$ EMAN Research and Testing Laboratory, School of Pharmaceutical Sciences, Universiti Sains Malaysia, 11800 Minden, Penang, Malaysia) \\ ${ }^{\dagger}$ E-mail: ismailzhari@gmail.com \\ Received Jan. 22, 2016; Revision accepted Mar. 25, 2016; Crosschecked Aug. 18, 2016
}

\begin{abstract}
Syzygium campanulatum Korth is a plant, which is a rich source of secondary metabolites (especially flavanones, chalcone, and triterpenoids). In our present study, three conventional solvent extraction (CSE) techniques and supercritical fluid extraction (SFE) techniques were performed to achieve a maximum recovery of two flavanones, chalcone, and two triterpenoids from $S$. campanulatum leaves. Furthermore, a Box-Behnken design was constructed for the SFE technique using pressure, temperature, and particle size as independent variables, and yields of crude extract, individual and total secondary metabolites as the dependent variables. In the CSE procedure, twenty extracts were produced using ten different solvents and three techniques (maceration, soxhletion, and reflux). An enriched extract of five secondary metabolites was collected using $n$-hexane:methanol (1:1) soxhletion. Using food-grade ethanol as a modifier, the SFE methods produced a higher recovery $(25.5 \%-84.9 \%)$ of selected secondary metabolites as compared to the CSE techniques $(0.92 \%-66.00 \%)$.
\end{abstract}

Key words: Syzygium campanulatum, Supercritical fluid extraction, Conventional solvent extractions, Flavanones, Chalcone, Triterpenoids

http://dx.doi.org/10.1631/jzus.B1600019

CLC number: 0658.2

\section{Introduction}

Syzygium campanulatum Korth is commonly found as an ornamental tree, primarily planted along roads and public places in Malaysia and Thailand. It is quite familiar as Kelat Paya in Malaysia (Nazarudin et al., 2010). Traditionally, it is reported as a stomachic (Memon et al., 2014). Scientifically, its $n$-hexane:

\footnotetext{
$\$$ Corresponding author

\# Electronic supplementary materials: The online version of this article (http://dx.doi.org/10.1631/jzus.B1600019) contains supplementary materials, which are available to authorized users

(D) ORCID: Zhari ISMAIL, http://orcid.org/0000-0002-0862-3507

(C) Zhejiang University and Springer-Verlag Berlin Heidelberg 2016
}

methanol ( $n$-HEX:MeOH) extract is characterized as (E)-2',4'-dihydroxy-6'-methoxy-3',5'-dimethylchalcone (DMC), (2S)-7-hydroxy-5-methoxy-6,8-dimethyl flavanone (HMDF), (S)-5,7-dihydroxy-6,8-dimethylflavanone (HMF), betulinic acid (BA), and ursolic acid (UA) (Memon et al., 2014; 2015). The $\mathrm{MeOH}$ extract of $S$. campanulatum has been analyzed for anticolon cancer activity (Aisha et al., 2013). In addition to $S$. campanulatum, flavanones, chalcones, and triterpenoids are also found as the most frequent secondary metabolites in other plants (Jäger et al., 2009; Oskoueian et al., 2013). Furthermore, these secondary metabolites possessed paramount pharmacological activities like anticancer (Wattenberg 
et al., 1994), analgesic, anti-inflammatory (Kim et al., 2010), antibacterial, antifungal, antiprotozoal (Gafner et al., 1996), and antiviral (Havsteen, 2002).

Generally, non-polar solvents ( $n$-HEX and chloroform) and polar solvents (acetone (Ace) and ethanol $(\mathrm{EtOH}))$ are reported for the extraction of aglycone flavonoids and flavonoids with glycones, respectively (Veličković et al., 2007). Chalcones, being semi-polar compounds, are extracted with a mixture of polar and non-polar solvents (Memon et al., 2014). Various methods of extraction, such as liquid solvent-based, ultrasound-assisted, pressurized liquid (Pinilla et al., 2014), soxhletion (Bimakr et al., 2011), heat reflux (Wong-Paz et al., 2014), and supercritical fluid extractions (Lien et al., 2014), are reported for maximum recoveries of flavonoids (He et al., 2005) and triterpenoids (Domingues et al., 2012) from various plants. In our present study, different conventional solvent extraction (CSE) and supercritical fluid extraction (SFE) techniques are performed and compared to achieve maximum recovery of abovementioned secondary metabolites from $S$. campanulatum leaves.

However, to our knowledge, a comparative study between CSE and SFE methods for the recovery of major secondary metabolites from $S$. campanulatum leaves has not yet been thoroughly performed. The main purpose of this study is to propose a suitable quality control method for extracting these five major secondary metabolites (two flavanones, chalcone, and two triterpenoids) from $S$. campanulatum leaves for industrial scale applications. Furthermore, ethanol was found as a modifier because it is environmentally benign and relatively safe for human health (He et al., 2005).

\section{Materials and methods}

\subsection{Plant materials}

The fresh leaves of the $S$. campanulatum plant were collected in June 2015, from the main campus of the Universiti Sains Malaysia (USM), Penang, Malaysia. The plant was authenticated by the School of Biological Sciences, USM, where a voucher specimen was deposited (Ref. No. 11047). The green leaves of the $S$. campanulatum plant were washed under tap water, dried in an oven at $40{ }^{\circ} \mathrm{C}$ for $2-3 \mathrm{~d}$, and finally ground to fine powder using an electric grinder (Retsch, Germany).

\subsection{Chemicals}

EtOH of food grade from chemical codex, $\mathrm{MeOH}, n$-HEX, ethyl acetate (EA) of analytical grade, hydrochloric acid $(\mathrm{HCl})$, sodium hydroxide $(\mathrm{NaOH})$, acetonitrile (ACN), Ace, orthophosphoric acid, BA, and UA of high performance liquid chromatography (HPLC) grade were purchased from Sigma-Aldrich, Germany, while HMDF, HMF, and DMC were isolated from the $S$. campanulatum extract. The carbon dioxide $\left(\mathrm{CO}_{2}\right)$ of SFE grade contained in a high pressure dip tube cylinder was purchased from Kras Instrument \& Services, Johor, Malaysia.

\subsection{Instruments}

The lab-scale super critical (SC)- $\mathrm{CO}_{2}$ unit consisted of an extraction vessel $(100 \mathrm{ml})$, high-pressure pump (Supercritical 24, Lab Alliance, USA), modifier pump (Series II Pump, Lab Alliance, USA), automated back pressure regulator (Jasco, BP-2080 Plus), oven-U10 (Memmert) used as an extraction chamber, and a 99\% pure $\mathrm{CO}_{2}$ tank (Kras Instrument \& Services, Johor, Malaysia). A pilot-scale $\mathrm{SC}-\mathrm{CO}_{2}$ extraction unit (SF5, Separex, France) with extraction vessel (5 L), Agilent HPLC 1260 system (USA), and ZORBAX Eclipse Plus Phenyl Hexyl $(4.6 \mathrm{~mm} \times 250 \mathrm{~mm}, 5 \mu \mathrm{m}) \mathrm{C}-18$ column (Agilent, USA) were also used.

\subsection{Methods of extraction}

\subsubsection{Lab-scale supercritical fluid extraction}

For the pilot-scale SFE method, a preliminary method was first optimized at the lab scale. A labscale $\mathrm{SC}-\mathrm{CO}_{2}$ unit was designed for the extraction of five major secondary metabolites from dried powdered leaves of the $S$. campanulatum plant. Experimental conditions were optimized as: pressure $(10,20$, and $30 \mathrm{MPa})$, temperature $\left(40,60\right.$, and $\left.80{ }^{\circ} \mathrm{C}\right)$, and particle size $(300,500$, and $700 \mu \mathrm{m})$ using EtOH as a modifier $\left(5 \%\right.$ of $\left.\mathrm{CO}_{2}\right)$ for the first hour, followed by a second hour of dynamic extraction in a solvent with a flow rate of $4 \mathrm{ml} / \mathrm{min}$ and plant mass of $10 \mathrm{~g}$. For comparing the effect of the modifiers, Ace and $\mathrm{MeOH}$ were used $\left(5 \%\right.$ of $\left.\mathrm{CO}_{2}\right)$ having a pressure of $30 \mathrm{MPa}$, temperature of $40{ }^{\circ} \mathrm{C}$, and particle size of $500 \mu \mathrm{m}$ for the same experimental time as mentioned for $\mathrm{EtOH}$. 
SFE crude extracts were collected in a vial $(25 \mathrm{ml})$ and kept at $4{ }^{\circ} \mathrm{C}$. Extracts were then evaporated to dryness using a rotary evaporator at $50{ }^{\circ} \mathrm{C}$. The experiment was performed based on the design that was developed using Statistica ${ }^{\circledR}$ (Version 8.0, StatSoft Inc.) and Design Expert ${ }^{\circledR}$ (Version 6.0.4, Stat-Ease Inc.). The Box-Behnken design was applied to assess the effects of processing parameters on response variables for the optimization of the extraction.

\subsubsection{Pilot-scale supercritical fluid extraction}

The pilot-scale extraction using $\mathrm{SC}-\mathrm{CO}_{2}$ (SF5, Separex, France) was performed according to the optimum results obtained from the Box-Behnken design. The pilot-scale $\mathrm{SC}-\mathrm{CO}_{2}$ was equipped with a high-pressure $\mathrm{CO}_{2}$ pump, back pressure regulator, chiller, extraction vessel $(5 \mathrm{~L})$, and separators. The extraction system was controlled automatically.

The $S$. campanulatum leaves were extracted using a modifier (EtOH) with dynamic extraction. Powdered dried leaves $(1 \mathrm{~kg})$ with $500-\mu \mathrm{m}$ particle size of the $S$. campanulatum plant were placed and sealed tightly in an extractor vessel $(5 \mathrm{~L})$. The temperature of the vessel, pre-heater, and separator was set at $50{ }^{\circ} \mathrm{C}$. Then, the vessel was inserted into its chamber. All manual valves were kept closed and $\mathrm{CO}_{2}$ inlet was opened slowly until the pressure became stable. The desired pressure ( $30 \mathrm{MPa}$ ) and flow rate $(35 \mathrm{~g} / \mathrm{min})$ were fixed. The extraction process was continued for the second hour of dynamic extraction by feeding the food-grade $\mathrm{EtOH}$ as a modifier at the ratio of $5 \%$ of $\mathrm{CO}_{2}$.

\subsubsection{Conventional solvent extraction}

For CSE, the dried powdered leaves $(200 \mathrm{~g})$ were extracted using three conventional methods of extraction (maceration (MAC), reflux (REF), and soxhletion (SOX)) and ten different solvents of $2 \mathrm{~L}$ (water, $0.1 \mathrm{~mol} / \mathrm{L} \mathrm{HCl}, 0.1 \mathrm{~mol} / \mathrm{L} \mathrm{NaOH}$ (at $95-$ $\left.100{ }^{\circ} \mathrm{C}\right), \mathrm{H}_{2} \mathrm{O}: \mathrm{EtOH}(1: 1, \mathrm{v} / \mathrm{v}), \mathrm{H}_{2} \mathrm{O}: \mathrm{MeOH}(1: 1, \mathrm{v} / \mathrm{v})$, EtOH, MeOH, EA, $n$-HEX, and $n$-HEX:MeOH (1:1), at $65-80{ }^{\circ} \mathrm{C}$ for $24 \mathrm{~h}$ ). The crude extracts were then filtered and concentrated to dryness using a rotary evaporator at $50{ }^{\circ} \mathrm{C}$.

\subsection{Analysis of secondary metabolites}

The quantifications of HMDF, HMF, DMC, BA, and UA in crude extracts were performed using the HPLC method as previously described (Memon et al.,
2015). Briefly, analysis was performed using a C-18 reverse phase ZORBAX Eclipse Plus Phenyl Hexyl column $(4.6 \mathrm{~mm} \times 250 \mathrm{~mm}, 5 \mu \mathrm{m})$. A mobile phase consisting of HPLC-grade ACN:Milli-Q $\mathrm{H}_{2} \mathrm{O}: \mathrm{H}_{3} \mathrm{PO}_{4}$ $(60: 40: 0.01, \mathrm{v} / \mathrm{v} / \mathrm{v})$ was used. Isocratic elution was performed keeping a flow rate of $1 \mathrm{ml} / \mathrm{min}$, at $30^{\circ} \mathrm{C}$, with a total run time $20 \mathrm{~min}$. The injection volume was $10 \mu \mathrm{l}$ and chromatograms were recorded at $210 \mathrm{~nm}$. Calibration curves of HMDF, HMF, DMC, $\mathrm{BA}$, and UA were plotted separately, using the already pure isolated compounds as standards.

\subsection{Experimental design and statistical analysis}

In this study, the Box-Behnken design consisting of fifteen runs, three factors, and three levels was employed for constructing a polynomial model for optimization of the maximum yields of crude extract, each secondary metabolite (HMDF, HMF, DMC, BA, and UA), and total secondary metabolites (TSM) as dependent variables using Statistica ${ }^{\circledR}$ (Version 8.0) and Design Expert $^{\circledR}$ (Version 6.0.4). The BoxBehnken design was selected as it generates fewer runs using three independent variables (Table 1).

Table 1 Independent and dependent variables and their levels in the Box-Behnken design

\begin{tabular}{ccccc}
\hline Level & \multicolumn{3}{c}{ Independent variables } & \multirow{2}{*}{$\begin{array}{c}\text { Dependent variable, } \\
Y(\%)\end{array}$} \\
\cline { 2 - 3 } & $X_{1}(\mathrm{MPa})$ & $X_{2}\left({ }^{\circ} \mathrm{C}\right)$ & $X_{3}(\mu \mathrm{m})$ & \\
\hline-1 & 10 & 40 & 300 & \\
0 & 20 & 60 & 500 & Maximize \\
1 & 30 & 80 & 700 & \\
\hline$X_{1}=$ pressure; $X_{2}=$ temperature; $X_{3}=$ particle size; $Y=$ yield
\end{tabular}

\section{Results and discussion}

\subsection{Conventional solvent extraction}

For CSE, ten different solvents and three methods of extraction were optimized and the yield of the crude extracts was calculated as the mean of duplicated experiments (Table 2). All the crude extracts were quantified using the HPLC method for quantification of major secondary metabolites and the representative chromatograms were recorded (Figs. 1 and S1). It was observed that a $0.1 \mathrm{~mol} / \mathrm{L} \mathrm{HCl-REF}$ method produced a higher yield of the crude extract $(30 \%)$ than the $n$-HEX:MeOH (1:1)-SOX (25\%). 
Table 2 Yields of crude extract (CE), total secondary metabolites (TSM), and individual secondary metabolites using CSE

\begin{tabular}{clccccccc}
\hline No. & \multicolumn{1}{c}{ Extraction } & CE (\%) & HMDF (\%) & HMF (\%) & DMC (\%) & BA (\%) & UA (\%) & TSM (\%) \\
\hline 1 & $\mathrm{H}_{2} \mathrm{O}-\mathrm{REF}$ & 20.0 & 0 & 0 & 0 & 0 & 0 & 0 \\
2 & $\mathrm{H}_{2} \mathrm{O}-\mathrm{MAC}$ & 5.0 & 0 & 0 & 0 & 0 & 0 & 0 \\
3 & 0.1 mol/L HCl-REF & 30.0 & 0 & 0 & 0 & 0 & 0 & 0 \\
4 & $0.1 \mathrm{~mol} / \mathrm{L} \mathrm{NaOH-REF}$ & 26.0 & 0 & 0 & 0 & 0 & 0 & 0 \\
5 & EtOH: $\mathrm{H}_{2} \mathrm{O}(1: 1)-\mathrm{SOX}$ & 12.0 & 0.05 & 0.02 & 0.05 & 0.8 & 0 & 0.92 \\
6 & EtOH: $\mathrm{H}_{2} \mathrm{O}(1: 1)-\mathrm{MAC}$ & 7.5 & 0.05 & 0.03 & 0.06 & 0.8 & 0 & 0.94 \\
7 & EtOH: $\mathrm{H}_{2} \mathrm{O}(1: 1)-\mathrm{REF}$ & 28.0 & 0.04 & 0.02 & 0.04 & 0.8 & 0 & 0.90 \\
8 & MeOH$: \mathrm{H}_{2} \mathrm{O}(1: 1)-\mathrm{SOX}$ & 14.0 & 0.05 & 0.08 & 0.08 & 2.3 & 0 & 2.51 \\
9 & MeOH:H$: \mathrm{O}(1: 1)-\mathrm{MAC}$ & 20.0 & 0.05 & 0.06 & 0.08 & 2.7 & 0 & 2.89 \\
10 & MeOH:H $\mathrm{O}(1: 1)-\mathrm{REF}$ & 27.0 & 0.05 & 0.09 & 0.10 & 2.4 & 0 & 2.64 \\
11 & EtOH-SOX & 26.0 & 1.30 & 0.24 & 2.30 & 35.0 & 2.8 & 41.64 \\
12 & EtOH-MAC & 14.0 & 1.00 & 0.17 & 2.80 & 40.0 & 3.5 & 47.47 \\
13 & EtOH-REF & 20.0 & 1.00 & 0.18 & 2.60 & 40.0 & 3.1 & 46.88 \\
14 & MeOH-SOX & 26.0 & 0.80 & 0.18 & 2.00 & 31.0 & 2.5 & 36.48 \\
15 & MeOH-MAC & 26.0 & 0.80 & 0.18 & 2.40 & 39.0 & 2.5 & 44.88 \\
16 & MeOH-REF & 21.0 & 0.70 & 0.17 & 2.10 & 33.0 & 2.3 & 38.27 \\
17 & $n$-HEX:MeOH (1:1)-SOX & 25.0 & 3.00 & 0.52 & 8.97 & 34.0 & 2.8 & 49.29 \\
18 & $n$-HEX:MeOH (1:1)-MAC & 26.0 & 1.20 & 0.19 & 4.50 & 19.0 & 3.8 & 28.69 \\
19 & $n$-HEX-MAC & 1.2 & 1.10 & 0.50 & 15.80 & 7.5 & 11.0 & 35.90 \\
20 & EA-MAC & 10.0 & 0.03 & 0.12 & 0.17 & 58.0 & 7.7 & 66.02 \\
\hline
\end{tabular}

In the $0.1 \mathrm{~mol} / \mathrm{L} \mathrm{HCl}-\mathrm{REF}$ crude extract, no HMDF, HMF, DMC, BA, or UA metabolite was recovered due to their insolubilities in water (Fig. 1a). The $n$-HEX:MeOH (1:1)-SOX extract produced maximum recoveries of $\mathrm{HMDF}, \mathrm{HMF}, \mathrm{DMC}, \mathrm{BA}$, and UA $(3.00 \%, 0.52 \%, 8.97 \%, 34.0 \%$, and $2.8 \%$; Fig. 1b). No recovery of TSM was obtained using $\mathrm{H}_{2} \mathrm{O}$, $0.1 \mathrm{~mol} / \mathrm{L} \mathrm{HCl}$ or $\mathrm{NaOH}$ solvents. With EtOH: $\mathrm{H}_{2} \mathrm{O}$ $(1: 1)$ and $\mathrm{MeOH}: \mathrm{H}_{2} \mathrm{O}(1: 1)$, there was no recovery of UA (Figs. 1c and 1d). The HMDF, HMF, DMC, and BA were recovered at $0.04 \%-0.05 \%, 0.02 \%-0.09 \%$, $0.04 \%-1.00 \%$, and $0.8 \%-2.7 \%$, respectively.

EtOH and $\mathrm{MeOH}$ recovered HMDF, HMF, DMC, BA, and UA at $0.7 \%-1.3 \%, 0.17 \%-0.24 \%$, $2.00 \%-2.80 \%, 31.0 \%-40.0 \%$, and $2.3 \%-3.5 \%$, respectively (Fig. S1). Fig. 1e shows a higher yield of DMC $(15.80 \%)$ from $n$-HEX-MAC. EA-MAC recovered the maxima of BA $(58.0 \%)$, while HMDF, HMF, DMC, and UA recovered $0.03 \%, 0.12 \%, 0.17 \%$, and $7.7 \%$, respectively (Fig. 1f). In all twenty CSE techniques, the maxima of HMDF, HMF, DMC, BA, and UA at $1.20 \%-3.00 \%, 0.19 \%-0.52 \%, 4.50 \%-8.97 \%$, $19.0 \%-34.0 \%$, and $2.8 \%-3.8 \%$ were recovered using the $n$-HEX:MeOH (1:1) SOX and MAC techniques.
The data of maximum recovery obtained by the CSE technique is summarized in Table 2.

\subsection{Supercritical fluid extraction}

\subsubsection{Preliminary study}

For SFE, the correlation between parameters was observed at the central point pressure of $30 \mathrm{MPa}$, and with particle size of $500 \mu \mathrm{m}$. The temperature at $40{ }^{\circ} \mathrm{C}$ and modifiers Ace, $\mathrm{MeOH}$, and $\mathrm{EtOH}$ were used to find a suitable extraction time and modifier. There was an increase in the extraction rate using $\mathrm{EtOH}$ as a modifier until $90 \mathrm{~min}$, followed by a 30-min period of a falling extraction rate. After $110 \mathrm{~min}$, no significant increase in the extraction of major secondary metabolites was observed. The 120 min experimental time was optimized with using $\mathrm{EtOH}$ as a modifier.

\subsubsection{Optimization of SFE using the Box-Behnken} experimental design

The Box-Behnken experimental design was developed to optimize the SFE method for maximum recovery of major secondary metabolites from the $S$. campanulatum leaves. The various parameters of design and recovery are summarized in Table 3 . 

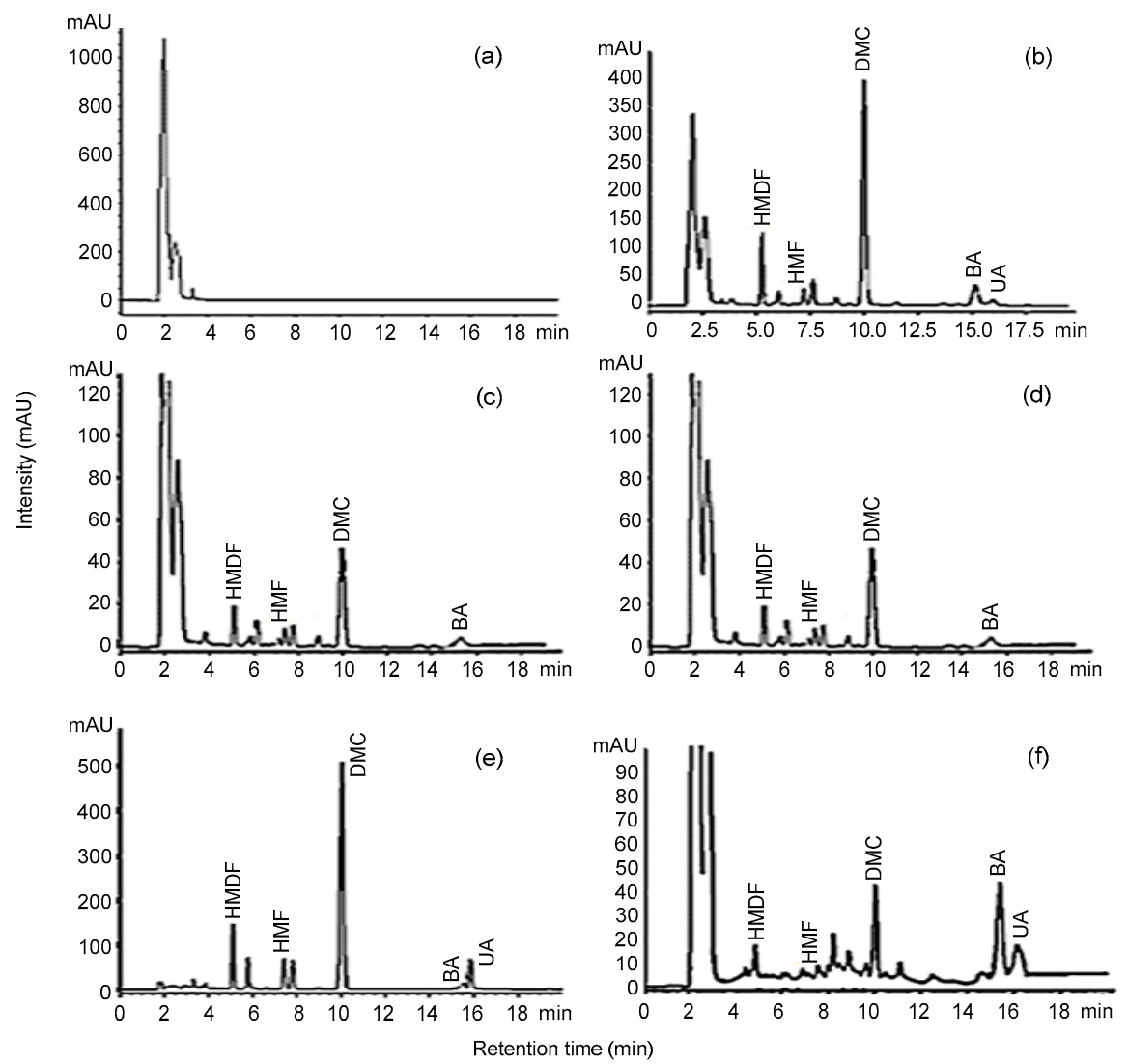

Fig. 1 Representative HPLC chromatograms of 6 CSE extracts from $\boldsymbol{S}$. campanulatum (a) 0.1 mol/L HCl-REF; (b) $n$-HEX:MeOH (1:1)-SOX; (c) EtOH:H $\mathrm{H}_{2} \mathrm{O}$ (1:1)-SOX; (d) MeOH:H $\mathrm{H}_{2} \mathrm{O}$ (1:1)-SOX; (e) $n$-HEXMAC; (f) EA-MAC

Table 3 Yields of crude extract (CE), total secondary metabolites (TSM), and individual secondary metabolites using the Box-Behnken experimental design for lab-scale SFE

\begin{tabular}{|c|c|c|c|c|c|c|c|c|c|c|}
\hline \multirow{2}{*}{ Run } & \multicolumn{3}{|c|}{ Design } & \multirow{2}{*}{$\begin{array}{l}\mathrm{CE} \\
(\%)\end{array}$} & \multirow{2}{*}{$\begin{array}{c}\mathrm{HMDF} \\
(\%)\end{array}$} & \multirow{2}{*}{$\begin{array}{c}\mathrm{HMF} \\
(\%)\end{array}$} & \multirow{2}{*}{$\begin{array}{c}\mathrm{DMC} \\
(\%)\end{array}$} & \multirow{2}{*}{$\begin{array}{l}\mathrm{BA} \\
(\%)\end{array}$} & \multirow{2}{*}{$\begin{array}{l}\text { UA } \\
(\%)\end{array}$} & \multirow{2}{*}{$\begin{array}{c}\text { TSM } \\
(\%)\end{array}$} \\
\hline & $X_{1}$ & $X_{2}$ & $X_{3}$ & & & & & & & \\
\hline 1 & -1 & -1 & 0 & 0.5 & 2.08 & 0.53 & 10.2 & 11.49 & 2.33 & 26.65 \\
\hline 2 & 1 & -1 & 0 & 1.1 & 3.31 & 0.87 & 18.0 & 24.79 & 4.96 & 51.98 \\
\hline 3 & -1 & 1 & 0 & 0.1 & 0.73 & 0.19 & 4.6 & 0 & 0 & 5.55 \\
\hline 4 & 1 & 1 & 0 & 1.3 & 2.26 & 0.58 & 12.8 & 21.31 & 9.25 & 46.25 \\
\hline 5 & -1 & 0 & -1 & 0.2 & 0.88 & 0.32 & 5.9 & 13.83 & 2.25 & 23.19 \\
\hline 6 & 1 & 0 & -1 & 0.8 & 2.37 & 0.64 & 12.9 & 21.84 & 3.23 & 41.00 \\
\hline 7 & -1 & 0 & 1 & 0.2 & 0.98 & 0.30 & 8.0 & 11.13 & 1.35 & 21.77 \\
\hline 8 & 1 & 0 & 1 & 0.8 & 3.00 & 0.80 & 17.2 & 20.79 & 2.96 & 44.80 \\
\hline 9 & 0 & -1 & -1 & 0.8 & 2.02 & 0.55 & 11.7 & 21.04 & 3.23 & 38.56 \\
\hline 10 & 0 & 1 & -1 & 1.7 & 1.88 & 0.54 & 8.2 & 8.16 & 3.34 & 22.12 \\
\hline 11 & 0 & -1 & 1 & 0.8 & 2.37 & 0.62 & 12.2 & 9.46 & 3.04 & 27.77 \\
\hline 12 & 0 & 1 & 1 & 1.6 & 2.09 & 0.50 & 11.1 & 6.98 & 2.07 & 22.82 \\
\hline 13 & 0 & 0 & 0 & 1.8 & 2.19 & 0.60 & 12.2 & 9.98 & 4.04 & 29.09 \\
\hline 14 & 0 & 0 & 0 & 1.8 & 2.04 & 0.58 & 13.0 & 9.89 & 4.26 & 29.79 \\
\hline 15 & 0 & 0 & 0 & 1.8 & 2.11 & 0.63 & 12.0 & 9.93 & 3.98 & 28.68 \\
\hline 16 & 0 & 0 & 0 & 1.7 & 2.34 & 0.65 & 11.8 & 9.90 & 4.00 & 28.88 \\
\hline 17 & 0 & 0 & 0 & 1.7 & 2.29 & 0.59 & 12.0 & 9.85 & 3.76 & 29.56 \\
\hline
\end{tabular}




\subsubsection{Statistical analysis}

The analysis of variance (ANOVA) was performed to fit the model for each variable. The statistical analysis for the regression of coefficients of different factors in all models is shown in Table 4. It was observed that pressure $\left(X_{1}\right)$ significantly influenced yields of crude extract, HMDF, HMF, DMC, $\mathrm{BA}, \mathrm{UA}$, and TSM in the linear model with positive coefficient values, whereas crude extract and BA also achieved similar results in their quadratic forms. This reflects the fact that the maximum yields of crude extract, HMDF, HMF, DMC, BA, UA, and TSM were achieved when pressure was set at its highest level, approximately $30 \mathrm{MPa}$ (Fig. 2).

On the other hand, the yield of crude extract decreased with the increase in pressure $\left(X_{1}\right)$.
Temperature $\left(X_{2}\right)$ significantly influenced the yields of HMDF, HMF, DMC, BA, and TSM in their linear form and UA in its quadratic form. It can be observed that the decrease in temperature increased the yields of HMDF, HMF, DMC, BA, and TSM (Figs. 2b, 2c, 2d, 2e, and 2g). The increased yields of $\mathrm{DMC}$ in its linear form and crude extract in its quadratic form were significantly influenced by particle size $\left(X_{3}\right)$. The coefficient of determination $\left(R^{2}\right)$ and the adjusted coefficient $\left(R_{\text {adj }}^{2}\right)$ of all models are presented in Table 4.

\subsubsection{Pilot-scale supercritical fluid extraction}

The pilot-scale SFE method at pressure $30 \mathrm{MPa}$ and temperature $40{ }^{\circ} \mathrm{C}$ and without a modifier produced a lower yield $(0.8 \%)$ of crude extract as compared with that using EtOH as a modifier (1.0\%).

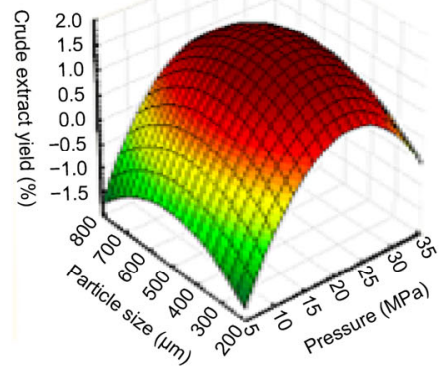

(a)

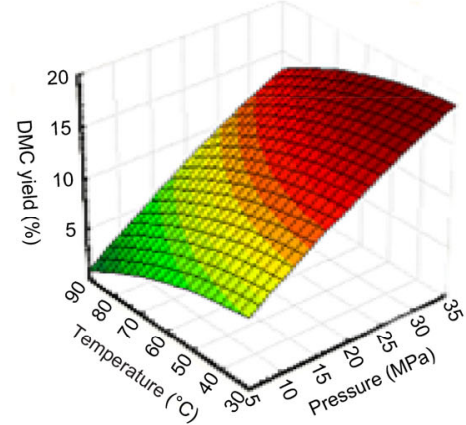

(d)

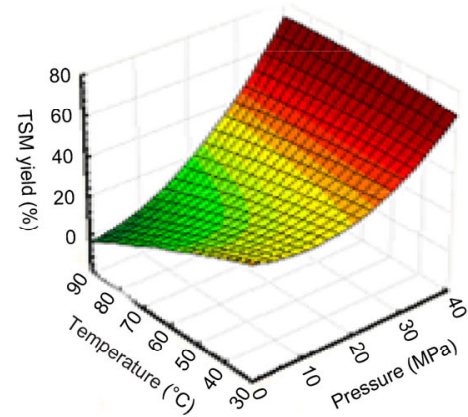

(g)

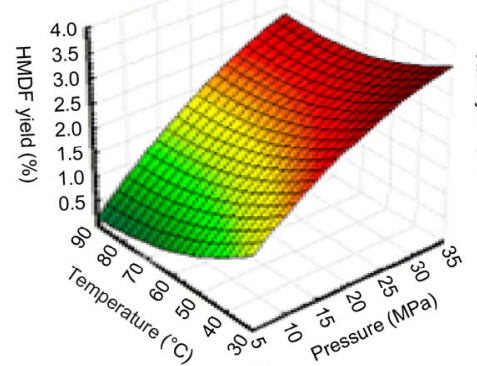

(b)

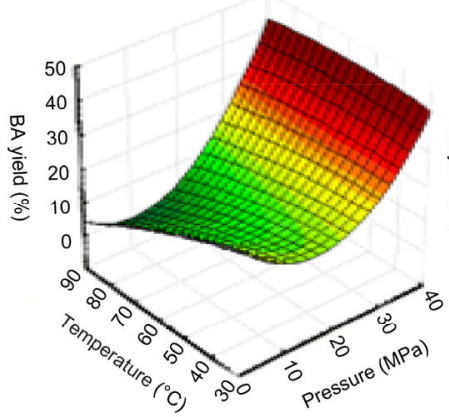

(e)

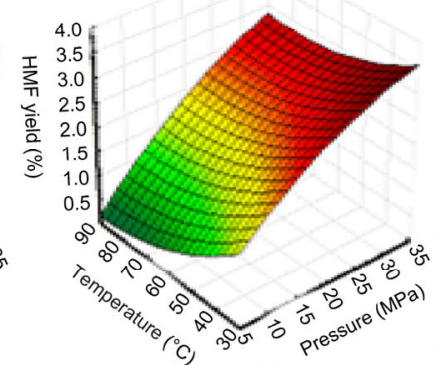

(c)

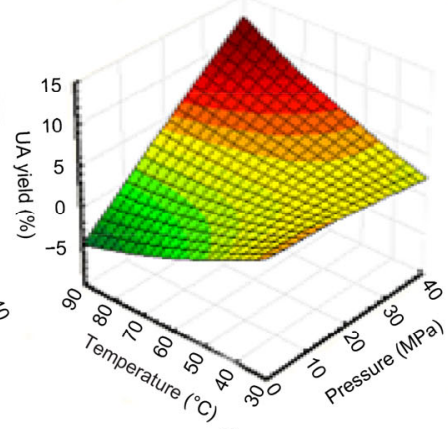

Fig. 2 Response surface analysis for the yields of crude extract (a), HMDF (b), HMF (c), DMC (d), BA (e), UA (f), and TSM (g) using SFE techniques 
Table 4 Model coefficients and regression adjustment of mathematical models obtained by response surface methodology for lab-scale SFE

\begin{tabular}{|c|c|c|c|c|c|c|c|c|c|c|c|c|c|c|}
\hline \multirow{2}{*}{$\begin{array}{l}\text { Effect on } \\
\text { yield }\end{array}$} & \multicolumn{7}{|c|}{ Coefficients } & \multicolumn{7}{|c|}{$P$} \\
\hline & $\mathrm{CE}$ & HMDF & HMF & DMC & BA & UA & TSM & $\mathrm{CE}$ & HMDF & HMF & DMC & BA & UA & TSM \\
\hline Intercept & 1.760 & 2.190 & 0.610 & 12.210 & 9.91 & 4.01 & 29.20 & 0.005 & 0.005 & 0.004 & 0.000 & 0.002 & 0.076 & 0.001 \\
\hline$X_{1}$ & 0.370 & 0.780 & 0.190 & 4.040 & 6.53 & 1.81 & 13.36 & 0.006 & 0.000 & 0.000 & 0.000 & 0.000 & 0.005 & 0.000 \\
\hline$X_{2}$ & 0.190 & -0.350 & -0.095 & -1.930 & -3.79 & 0.14 & -6.03 & 0.088 & 0.012 & 0.007 & 0.000 & 0.004 & 0.774 & 0.003 \\
\hline$X_{3}$ & $-7.50 \times 10^{-3}$ & 0.160 & 0.021 & 1.250 & -2.06 & -0.33 & -0.96 & 0.940 & 0.170 & 0.436 & 0.008 & 0.057 & 0.499 & 0.500 \\
\hline$X_{1}^{2}$ & -0.880 & -0.190 & -0.053 & -0.300 & 4.99 & -0.17 & 4.14 & 0.000 & 0.231 & 0.182 & 0.551 & 0.005 & 0.793 & 0.062 \\
\hline$X_{2}^{2}$ & -0.140 & 0.092 & -0.015 & -0.480 & -0.50 & 0.30 & -0.73 & 0.337 & 0.548 & 0.685 & 0.352 & 0.701 & 0.651 & 0.707 \\
\hline$X_{3}^{2}$ & -0.390 & -0.200 & -0.042 & -0.890 & 2.00 & -1.39 & -0.65 & 0.022 & 0.220 & 0.270 & 0.104 & 0.153 & 0.065 & 0.738 \\
\hline$X_{1} X_{2}$ & 0.150 & 0.075 & 0.012 & 0.097 & 2.00 & 1.65 & 3.84 & 0.308 & 0.631 & 0.741 & 0.848 & 0.162 & 0.038 & 0.085 \\
\hline$X_{1} X_{3}$ & $-2.50 \times 10^{-3}$ & 0.130 & 0.045 & 0.560 & 0.41 & 0.16 & 1.31 & 0.985 & 0.404 & 0.560 & 0.293 & 0.757 & 0.816 & 0.518 \\
\hline$X_{2} X_{3}$ & -0.018 & -0.035 & -0.028 & 0.610 & 2.60 & -0.27 & 2.87 & 0.901 & 0.821 & 0.475 & 0.257 & 0.082 & 0.691 & 0.178 \\
\hline$R^{2}$ & 0.916 & 0.913 & 0.916 & 0.963 & 0.934 & 0.798 & 0.948 & - & - & - & - & - & - & - \\
\hline$R_{\text {adj }}^{2}$ & 0.808 & 0.801 & 0.809 & 0.917 & 0.851 & 0.538 & 0.882 & - & - & - & - & - & - & - \\
\hline
\end{tabular}

$P$ value of $<0.05$ is considered significant. CE: crude extract

Table 5 Yields of crude extract (CE), total secondary metabolites (TSM), and individual secondary metabolites using the pilot-scale SFE technique

\begin{tabular}{clccccccc}
\hline No. & \multicolumn{1}{c}{ Extraction } & CE (\%) & HMDF (\%) & HMF (\%) & DMC (\%) & BA (\%) & UA (\%) & TSM (\%) \\
\hline 1 & The first hour without modifier & 0.8 & 3.1 & 0.98 & 21.05 & 0.40 & 0 & 25.53 \\
2 & The first hour with modifier & 1.0 & 5.7 & 0.96 & 18.07 & 45.20 & 4.6 & 74.53 \\
3 & The second hour with modifier & 1.0 & 4.9 & 0.89 & 17.22 & 57.35 & 4.5 & 84.86 \\
\hline
\end{tabular}

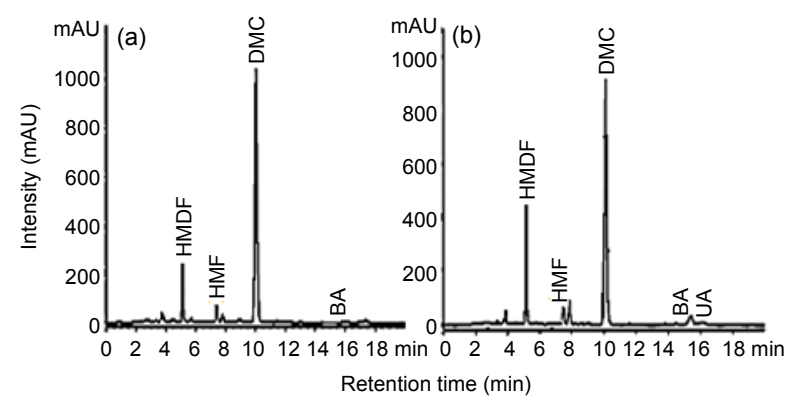

Fig. 3 Representative HPLC chromatograms of pilotscale SFE with and without a modifier

(a) The first hour extraction without a modifier at pressure

$30 \mathrm{MPa}$, temperature $40{ }^{\circ} \mathrm{C}$, and particle size $500 \mu \mathrm{m}$;

(b) The first hour extraction with a modifier at pressure

$30 \mathrm{MPa}$, temperature $40^{\circ} \mathrm{C}$, and particle size $500 \mu \mathrm{m}$

In the first hour of extraction without a modifier, HMDF, HMF, DMC, and BA were recovered at 3.1\%, $0.98 \%, 21.05 \%$, and $0.40 \%$, respectively, while UA was not recovered without a modifier. In the first hour of extraction without a modifier, HMF and DMC were recovered at their highest yields (Fig. 3a). During the first hour of extraction with a modifier, the highest yields of HMDF and UA were observed (Fig. 3b). In the second hour extraction, the maximum yield was observed for BA. Table 5 summarizes the yield for the pilot-scale SFE. All respective chromatograms are shown in Fig. S2.

\section{Conclusions}

S. campanulatum leave extracts produced a higher yield of TSM by different CSE methods. High recoveries of HMDF $(3.00 \%)$ and HMF $(0.52 \%)$ were obtained using $n$-HEX:MeOH-SOX, DMC (15.80\%) and UA (11.0\%) using $n$-HEX-MAC, and BA (58.0\%) using EA-MAC. 
In the pilot-scale SFE, the highest recoveries of HMF and DMC were observed within the first hour of extraction without a modifier $(\mathrm{EtOH})$. The maximum recoveries of HMDF and UA were obtained during the first hour of extraction with a modifier. In the second hour of SFE extraction with a modifier $(\mathrm{EtOH}), \mathrm{BA}$ was recovered at its highest yield. Using the lab-scale and pilot-scale SFE methods allows us to postulate that EtOH used as a modifier has a significant effect on the recovery of secondary metabolites from dried leaves of $S$. campanulatum. From the present study, it can be concluded that the pilot-scale SFE method is better than CSE in terms of less consumption of plant raw material, solvent, and time. The CSE methods are not constantly acceptable for industrial applications due to more time required for extraction, consumption of hazardous and expensive solvents, and more use of raw material and labor. Therefore, the developed SFE method can be an alternative extraction method to CSE for extraction of secondary metabolites from the leaves of the $S$. campanulatum plant.

\section{Acknowledgements}

The authors are thankful to the Universiti Sains Malaysia for providing financial support.

\section{Compliance with ethics guidelines}

Abdul Hakeem MEMON, Mohammad Shahrul Ridzuan HAMIL, Madeeha LAGHARI, Fahim RITHWAN, Salman ZHARI, Mohammed Ali Ahmed SAEED, Zhari ISMAIL, and Amin Malik Shah Abdul MAJID declare that they have no conflict of interest.

This article does not contain any studies with human or animal subjects performed by any of the authors.

\section{References}

Aisha, A.F.A., Ismail, Z., Abu-Salah, K.M., et al., 2013. Syzygium campanulatum Korth methanolic extract inhibits angiogenesis and tumor growth in nude mice. $B M C$ Complement. Altern. Med., 13:168-179. http://dx.doi.org/10.1186/1472-6882-13-168

Bimakr, M., Rahman, R.A., Taip, F.S., et al., 2011. Comparison of different extraction methods for the extraction of major bioactive flavonoid compounds from spearmint (Mentha spicata L.) leaves. Food Bioprod. Process., 89(1):67-72. http://dx.doi.org/10.1016/j.fbp.2010.03.002

Domingues, R.M.A., Oliveira, E.L.G., Freire, C.S.R., et al., 2012. Supercritical fluid extraction of Eucalyptus globulus Bark - a promising approach for triterpenoid production.
Int. J. Mol. Sci., 13(6):7648-7662.

http://dx.doi.org/10.3390/ijms13067648

Gafner, S., Wolfender, J.L., Mavi, S., et al., 1996. Antifungal and antibacterial chalcones from Myrica serrata. Planta Med., 62(1):67-69. http://dx.doi.org/10.1055/s-2006-957804

Havsteen, B.H., 2002. The biochemistry and medical significance of the flavonoids. Pharmacol. Ther., 96(2-3): 67-202.

He, G.Q., Xiong, H.P., Chen, Q.H., et al., 2005. Optimization of conditions for supercritical fluid extraction of flavonoids from hops (Humulus lupulus L.). J. Zhejiang Univ.-Sci. B, 6(10):999-1004. http://dx.doi.org/10.1631/jzus.2005.B0999

Jäger, S., Trojanet, H., Kopp, T., et al., 2009. Pentacyclic triterpene distribution in various plants - rich sources for a new group of multi-potent plant extracts. Molecules, 14(6):2016-2031. http://dx.doi.org/10.3390/molecules14062016

Kim, Y.J., Ko, H., Park, J.S., et al., 2010. Dimethyl cardamonin inhibits lipopolysaccharide-induced inflammatory factors through blocking $\mathrm{NF}-\mathrm{\kappa B}$ p65 activation. Int. Immunopharmacol., 10(9):1127-1134. http://dx.doi.org/10.1016/j.intimp.2010.06.017

Lien, H.M., Chiu, C.H., Chen, C.C., et al., 2014. Comparison of the apoptotic effects of supercritical fluid extracts of Antrodia cinnamomea mycelia on hepatocellular carcinoma cells. Molecules, 19(7):9033-9050. http://dx.doi.org/10.3390/molecules 19079033

Memon, A.H., Ismail, Z., Aisha, A.F.A., et al., 2014. Isolation, characterization, crystal structure elucidation, and anticancer study of dimethyl cardamonin, isolated from Syzygium campanulatum Korth. Evid.-Based Complement. Altern. Med., 2014:470179.

http://dx.doi.org/10.1155/2014/470179

Memon, A.H., Ismail, Z., Al-Suede, F.S.R., et al., 2015. Isolation, characterization, crystal structure elucidation of two flavanones and simultaneous RP-HPLC determination of five major compounds from Syzygium campanulatum Korth. Molecules, 20(8):14212-14233. http://dx.doi.org/10.3390/molecules200814212

Nazarudin, A., Ying, T.F., Ramlan, M.F., 2010. Growth inhibition of Syzygium campanulatum Korth. for container planting by the application of uniconazole. Pertanika J. Trop. Agric. Sci., 33(1):1-6.

Oskoueian, E., Abdullah, N., Armin Oskoueian, A., 2013. Effects of flavonoids on rumen fermentation activity, methane production, and microbial population. BioMed Res. Int., 2013:349129. http://dx.doi.org/10.1155/2013/349129

Pinilla, J.M., López-Padilla, A., Vicente, G., et al., 2014. Recovery of betulinic acid from plane tree (Platanus acerifolia L.). J. Supercrit. Fluids, 95:541-545. http://dx.doi.org/10.1016/j.supflu.2014.09.001 
Veličković, D.T., Nikolova, M.T., Ivancheva, S.V., et al., 2007. Extraction of flavonoids from garden (Salvia officinalis L.) and glutinous (Salvia glutinosa L.) sage by ultrasonic and classical maceration. J. Serb. Chem. Soc., 72(1):73-80. http://dx.doi.org/10.2298/JSC0701073V

Wattenberg, L.W., Coccia, J.B., Galbraith, A.R., 1994. Inhibition of carcinogen-induced pulmonary and mammary carcinogenesis by chalcone administered subsequent to carcinogen exposure. Cancer Lett., 83(1-2):165-169. http://dx.doi.org/10.1016/0304-3835(94)90314-X

Wong-Paz, J.E., Muñiz-Márquez, D.B., Aguilar-Zárate, P., et al., 2014. Microplate quantification of total phenolic content from plant extracts obtained by conventional and ultrasound methods. Phytochem. Anal., 25(5):439-444. http://dx.doi.org/10.1002/pca.2512

\section{List of electronic supplementary materials}

Fig. S1 Representative HPLC chromatograms of other 14 CSE extracts from $S$. campanulatum

Fig. S2 Representative HPLC chromatograms of lab-scale and pilot-scale SFE extracts from $S$. campanulatum at different pressures, temperatures, and particle sizes

\section{中文概要}

题 目: 传统溶剂提取法和超临界流体萃取法对钟花蒲桃 次生代谢产物的回收率的比较研究

目 的: 寻求一种最佳的钟花蒲桃次生代谢产物的萃取方 法，以实现在工业上的应用。

创新点: 全面深入地比较传统溶剂提取法和超临界流体萃 取法对钟花蒲桃的主要次生代谢产物的回收率。

方 法: 在超临界流体萃取法中, 应用Box-Behnken 设计, 以压力、温度和萃取粒径大小为自变量, 以粗提 取物、个别的和总的次生代谢产物的百分比产量 为因变量。另外, 还研究了调节剂乙醇对产量的 影响。在传统溶剂提取中, 结合十种不同的溶剂 和三不同的技术（浸提、索氏和回流）产生二十 种不同的提取产物。通过高效液相色谱法检测不 同的提取方法对钟花蒲桃的主要次生代谢产物 的回收率。

结 论: 超临界流体萃取法优于传统溶剂提取法, 省成本 又省时。因此在工业使用上, 超临界流体萃取法 可替代传统溶剂提取法。

关键词: 钟花蒲桃; 超临界流体萃取法; 传统溶剂提取法; 黃烷酮类化合物; 查耳酮类化合物; 三萜类化合 物 